\title{
Management by the intensivist of gastrointestinal bleeding in adults and children
}

\author{
David Osman ${ }^{1 *}$, Michel Djibré ${ }^{2}$, Daniel Da Silva ${ }^{3}$, Cyril Goulenok $^{4}$ and for the group of experts
}

\begin{abstract}
Intensivists are regularly confronted with the question of gastrointestinal bleeding. To date, the latest international recommendations regarding prevention and treatment for gastrointestinal bleeding lack a specific approach to the critically ill patients. We present recommendations for management by the intensivist of gastrointestinal bleeding in adults and children, developed with the GRADE system by an experts group of the French-Language Society of Intensive Care (Société de Réanimation de Langue Française (SRLF), with the participation of the French Language Group of Paediatric Intensive Care and Emergencies (GFRUP), the French Society of Emergency Medicine (SFMU), the French Society of Gastroenterology (SNFGE), and the French Society of Digestive Endoscopy (SFED). The recommendations cover five fields of application: management of gastrointestinal bleeding before endoscopic diagnosis, treatment of upper gastrointestinal bleeding unrelated to portal hypertension, treatment of upper gastrointestinal bleeding related to portal hypertension, management of presumed lower gastrointestinal bleeding, and prevention of upper gastrointestinal bleeding in intensive care.
\end{abstract}

Keywords: Gastrointestinal bleeding, Intensive care, Ulcer, Gastric/esophageal varices, Recommendations

\section{Review}

\section{Introduction}

Intensivists are regularly confronted with the question of gastrointestinal (GI) bleeding. They notably need to manage acute GI bleeding, a frequent and severe condition [1], the mortality of which has probably not changed for 20 years [1] but could be reduced through recent diagnostic and therapeutic advances [2]. They also should define, for each patient admitted to intensive care, how to prevent upper GI bleeding related to "stress ulceration". a now uncommon complication [3], but for which drug prophylaxis is widely used [4] and often involves proton pump inhibitors (PPIs) [4]. Because the latest international recommendations for the management of acute nonvariceal upper GI bleeding [2] or for GI bleeding related to portal hypertension [5] lack a specific approach to severe forms, and because the French consensus conference on prevention of "stress-related" upper GI bleeding in intensive care was nearly 25 years ago [6], we decided to draw up these recommendations (Table 1 ).

\footnotetext{
* Correspondence: david.osman@bct.aphp.fr

${ }^{1}$ AP-HP, Hôpitaux universitaires Paris-Sud, Hôpital de Bicêtre, Service de réanimation médicale, Le Kremlin-Bicêtre, F-94270, France

Full list of author information is available at the end of the article
}

\section{Methodology}

The SRLF brought together a group of experts representing the various disciplines involved in the management of severe GI bleeding (critical care, hepatogastroenterology, emergency care, radiology, surgery, pediatrics) to draw up these recommendations. The organizing committee and the coordinator first defined the questions to be considered and designated the experts responsible for each question. Using the GRADE system (Grading of Recommendations, Assessment, Development and Evaluation) [7,8], the literature was analyzed and recommendations were formulated. A level of proof was defined for each literature reference according to the type of study, and could be reevaluated taking into account the methodological quality of the study. The literature references common to each assessment criterion were then grouped. An overall level of proof was determined for each assessment criterion taking into account the levels of proof of each literature reference, the consistency of the results between the different studies, the cost-effectiveness analysis, the directness of the evidence, etc. A "strong" level of proof enabled a "strong" recommendation ("must be done," "must not be done..."). A "moderate," "weak," or "very weak" level of proof resulted in a "conditional" recommendation ("should 


\section{Table 1 Recommendations for management by the intensivist of gastrointestinal bleeding}

consequences, and when $\mathrm{Gl}$ endoscopic findings are normal, an emergency scintigraphy to search for a Meckel's diverticulum of rebleeding (Forrest type la, lb, $\| \mathrm{l}$ a, llb), PPI treatment should be used and/or a surgical exploration (McBurney's should be continued at "high" doses for $72 \mathrm{~h}$ incision or coelioscopy) (strong agreement) \begin{tabular}{lll}
\hline & Nasogastric intubation may help confirm, but cannot discount, 12 & Vasoactive treatment (terlipressin or somatostatin \\
suspected upper Gl bleeding (strong agreement) & derivative) should be administered as soon as possible
\end{tabular} suspected upper Gl bleeding (strong agreement) when portal hypertension is the suspected cause if

strong agreement) Gl bleeding (strong agreement)

2 Suspected rupture of esophageal/gastric varices probably does not contraindicate nasogastric intubation (strong agreement)

13 In a patient already treated with noradrenaline, specific vasoactive treatment of the splanchnic area (terlipressin somatostatin, somatostatin derivative) should probably be administered when portal hypertension is the suspected cause of $G$ bleeding rexpert

14 Specific vasoactive treatment of the splanchnic area (terlipressin, somatostatin, somatostatin derivative) should probably not be administered when portal hypertension is not the suspected cause of GI bleeding (weak agreement) intravenous erythromycin should be administered at a dose of $250 \mathrm{mg}(5 \mathrm{mg} / \mathrm{kg}$ in children), in the absence of contraindications (strong agreement)

4 If a nasogastric tube has been inserted, gastric lavage to empty the stomach is an alternative to administration of erythromycin (weak agreement)

15 In Gl bleeding potentially caused by ulcers, PPI treatment should be started without waiting for endoscopic diagnosis (weak agreement)

5 In adults, the Rockall score and the Glasgow-Blatchford bleeding score can probably help to identify patients at high risk of morbidity and mortality and to refer them to an intensive care unit (strong agreement)

16 In Gl bleeding potentially caused by ulcers, high-dose PPI treatment should probably be administered (weak agreement)

6 EGD should be done in the $24 \mathrm{~h}$ following the admission of the patient with suspected upper Gl bleeding (strong agreement)

$7 \quad$ EGD should be probably done in the b12 $\mathrm{h}$ following the admission of the patient with suspected esophageal/gastric variceal bleeding (strong agreement)

8 EGD should be probably done as soon as possible, and once the patient is resuscitated, when active upper Gl bleeding is suspected (strong agreement)

9 In massive hematochezia and/or hemodynamic consequences, an EGD should be performed as soon as possible (strong agreement)

10 In adults, in massive hematochezia and/or with hemodynamic consequences, a CT angiography should be performed in emergency, if EGD is not rapidly available and/or if an aortoenteric fistula is suspected (strong agreement)
Area 2: Treatment of upper Gl bleeding unrelated to

portal hypertension

1 In the presence of stigmata associated with a low risk of rebleeding (Forrest type IIC and III), endoscopic hemostasis should not be used (strong agreement)

2 In the presence of stigmata associated with a low risk of rebleeding (Forrest type IIC and III), PPI treatment

3 In the presence of stigmata associated with a high risk of rebleeding (Forrest type la, lb, Ila), endoscopic hemostasis should be performed (strong agreement)

In the presence of an adherent clot (Forrest type llb) endoscopic hemostasis is possible when the clot is small (strong agreement) at "standard" doses should be continued (strong agreement)
6 Second-look EGD should not be done routinely (strong agreement

Second-look EGD should probably be done when a high-risk stigmata has been observed(weak agreement)

8 Patients with ulcer bleeding should not be treated with $\mathrm{H}_{2}$ receptor antagonists (strong agreement)

9 In adults, in case of Forrest type la and Ib, firstintention selective arterial embolization by interventional radiology should probably be used following failure of endoscopic therapy (weak agreement)

10 In adults, in case of Forrest type la and Ib and catastrophic bleeding, first-intention surgical hemostasis should probably be used following failure of endoscopic therapy if local conditions do not allow arterial embolization(strong agreement)

11 Biopsy screening for Helicobacter pylori infection can be performed during the first EGD for Gl bleeding without worsening the bleeding (strong agreement)

12 There is probably no advantage to emergency treatment of Helicobacter pylori infection in the case of $\mathrm{Gl}$ ulcer bleeding (strong agreement)

13 Aspirin antiplatelet therapy should probably be maintained in the case of Gl ulcer bleeding until consultation with specialists (weak agreement)

14 In dual antiplatelet therapy, clopidogrel should probably be stopped in the case of ulcer bleeding until consultation with specialists (strong agreement)

Area 3: Treatment of upper Gl bleeding related to portal
hypertension 
1 Endoscopic therapy of bleeding esophageal/gastric varices should be done during initial EGD (strong agreement)

2 Endoscopic therapy of bleeding esophageal varices is based on band ligation. Sclerotherapy is an alternative in the very young child (strong agreement)

3 Endoscopic therapy of bleeding gastric varices is based on obturation with tissue adhesives (strong agreement)

$4 \quad$ Vasoactive treatment should be continued for 3 to 5 days after endoscopic therapy of esophageal/gastric varices rupture (strong agreement)

5 In adults, after endoscopic hemostasis of bleeding related to portal hypertension, the placement of a TIPS within $72 \mathrm{~h}$ should be considered in high-ris patients (strong agreement)

6 Balloon tamponade should be considered after endoscopy failure pending radical treatment of portal hypertension. In child, its use should probably be envisaged if emergency EGD is not possible (strong agreement)

7 Antibiotic prophylaxis with third-generation cephalosporin or with fluoroquinolone for 5 to 7 days should be given to any cirrhotic patient with Gl bleeding (strong agreement)

8 Lactulose treatment to prevent hepatic encephalopathy should probably not be initiated during Gl bleeding in a cirrhotic patient (expert opinion, strong agreement)

9 In adults, PPI therapy should not be initiated or continued when EGD has confirmed a diagnosis of ruptured esophageal/gastric varices (strong agreement)

10 In children, PPI therapy should probably be initiated or continued in case of esophageal/gastric varices rupture (weak agreement)

11 One objective of hemodynamic treatment during esophageal/gastric varices rupture should be to restore a satisfactory mean blood pressure to preserve tissue perfusion (strong agreement)

12 In adults, during esophageal/gastric varices rupture, early hemodynamic treatment should probably maintain mean blood pressure at approximately $65 \mathrm{mmHg}$ in most patients (strong agreement)
13 Blood transfusion in most patients should probably target a hemoglobin concentration of 7 to $8 \mathrm{~g} / \mathrm{dL}$ (strong agreement)

14 In Gl bleeding in patients with cirrhosis, there is probably no indication for administration of fresh-frozen plasma with the objective to correct a coagulopathy (strong agreement)

15 In Gl bleeding in patients with cirrhosis, there is no indication for administration of fresh-frozen plasma before EGD (strong agreement)

16 In Gl bleeding in patients with cirrhosis, there is no indication for the administration of factor Vlla (strong agreement)

17 In Gl bleeding in patients with cirrhosis, platelet transfusion should probably be considered when bleeding is uncontrolle and platelet count is $<30,000 / \mathrm{mm}^{3}$ (strong agreement)

18 In adults, in esophageal/gastric bleeding, beta-blocker treatment 2 should be started when vasoactive treatment is discontinued (strong agreement)

5 When lower Gl bleeding is massive, surgical hemostasis should be proposed in case of arterial embolization or colonoscopy failure or rebleeding (strong agreement)

6 When lower Gl bleeding is catastrophic, surgical hemostasis should be performed if arterial embolization is not possible under local conditions (strong agreement)

In massive or persistent lower Gl bleeding, the small intestine should be examined as soon as possible when $\mathrm{C}$ angiography and colonoscopy fail to locate the source of bleeding (strong agreement)

Area 5: Prevention of upper Gl bleeding in intensive care

Patients with a history of peptic ulcer admitted to intensive care should probably be considered at risk of Gl bleeding (strong agreement)

Early enteral feeding is effective in preventing "stress ulcer" bleeding (strong agreement)

19 After ligation of esophageal varices, nasogastric intubation should probably be avoided (expert opinion, strong agreement)

Patients requiring mechanical ventilation for more than $48 \mathrm{~h}$ and for whom enteral feeding is not possible should be considered to be at risk of "stress ulcer" bleeding (strong agreement)

Area 4: Management of presumed lower Gl bleeding

Patients admitted to intensive care with kidney failure and/or coagulopathy and/or receiving antiplatelet therapy should be considered to be at risk of "stress ulcer" bleeding (strong agreement)

In adults with massive hematochezia, demonstration of active bleeding by abdominal CT angiography or arteriography justifies embolization as first-line therapy (strong agreement)

Routine drug prophylaxis of "stress ulcer" should not be used in intensive care patients with enteral feeding (strong agreement)

2 In massive hematochezia, and in the absence of detectable bleeding on $\mathrm{CT}$ angiography or arteriography a prepared colonoscopy should be performed within $24 \mathrm{~h}$ (strong agreement)

6 Ulcer prophylaxis medication should probably be

given routinely in intensive care patients with a history given routinely in intensive care patients with a history
of peptic ulcer (even if enterally fed) (weak agreement)

3 In massive and persistent hematochezia, and in the absence of detectable bleeding on abdominal CT angiography or arteriography, a prepared colonoscopy should probably be done within $12 \mathrm{~h}$ with the objective of performing endoscopic hemostasis (strong agreement)

Ulcer prophylaxis medication should probably be given routinely to intensive care patients receiving antiplatelet therapy (even if enterally fed) (weak agreement)

In adults with massive hematochezia, rectosigmoidoscopy should probably be done if full colonoscopy cannot be performed within $24 \mathrm{~h}$ (strong agreement)
8 In the absence of enteral feeding, ulcer prophylaxis medication should probably be given to ventilated patients (weak agreement) 
Table 1 Recommendations for management by the intensivist of gastrointestinal bleeding (Continued)

9 In the absence of enteral feeding, ulcer prophylaxis 13 A large bore nasogastric tube for aspiration should

medication should

coagulopathy (weak agreement)

13 A large bore nasogastric tube for aspiration should
probably be replaced by a small-calibre enteral

tube as soon as possible (expert opinion, strong

agreement)

10 In children, a pediatric risk of mortality score (PRISM) > 14 Antacids should not be used to prevent "stress ulcer" 10 associated with respiratory failure or coagulopathy bleeding (strong agreement)

or both probably calls for ulcer prophylaxis (strong

agreement)

11 Screening for Helicobacter pylori should not be routine in intensive care patients (strong agreement)

$15 \mathrm{H}_{2}$ receptor antagonists and PPIs are probably comparable but of low efficacy in preventing "stress ulcer" bleeding (weak agreement)

12 A nasogastric tube should probably be removed once it is no longer used (expert opinion, strong agreement)

$16 \mathrm{H}_{2}$ receptor antagonists and PPIs are probably comparable regarding the risk ventilator associated pneumonia during mechanical ventilation (strong agreement)

$\overline{\mathrm{Gl}}$, gastrointestinal; EGD,esophagogastroduodenoscopy; TIPS, transjugular intrahepatic protosystemic shunt. 
Table 2 Rockall score

\begin{tabular}{|c|c|c|c|c|}
\hline Score & 0 & 1 & 2 & 3 \\
\hline Age (yr) & $<60$ & $60-70$ & $>80$ & \\
\hline \multirow[t]{2}{*}{ Shock } & No shock & Pulse $>100$ & & \\
\hline & & $\mathrm{SBP}>100 \mathrm{mmHg}$ & & \\
\hline \multirow[t]{3}{*}{ Comorbidity } & No & No & Ischemic heart disease & Renal failure \\
\hline & & & Cardiac failure & Liver failure \\
\hline & & & Major comorbidity & Disseminated malignancy \\
\hline \multirow[t]{2}{*}{ Diagnosis } & Mallory Weiss tear or & All other diagnoses & Gastrointestinal malignancy & \\
\hline & No lesion & & & \\
\hline \multirow[t]{3}{*}{ Evidence of bleeding } & None or & & Blood & \\
\hline & Dark spot & & Visible or spurting vessel & \\
\hline & & & Adherent clot & \\
\hline
\end{tabular}

A total score less than 3 carries good prognosis and total score more than 8 carries high risk of mortality.

SBP, systolic blood vessel.

From Rockall TA, Gut 1996.

probably be done", "should probably not be done..."). The proposed recommendations were presented and discussed one by one. The aim was not necessarily to reach a single and convergent opinion for all proposals, but rather to highlight points of agreement, and points of disagreement or indecision. Each recommendation was then scored by each of the experts on a scale of 1 (complete disagreement) to 9 (complete agreement). The collective scoring was established using the RAND/UCLA appropriateness method [9]: after elimination of the extreme values (outliers), the median and confidence interval of the individual

\section{Table 3 Glasgow-Blatchford score}

\begin{tabular}{|c|c|c|}
\hline Admission risk marker & & Score \\
\hline \multirow[t]{4}{*}{ Blood urea $(\mathrm{mmol} / \mathrm{l})$} & $\geq 6.5$ et $<8$ & 2 \\
\hline & $\geq 8$ et $<10$ & 3 \\
\hline & $\geq 10$ et $<25$ & 4 \\
\hline & $\geq 25$ & 6 \\
\hline \multirow[t]{3}{*}{ Hemoglobin $(g / L)$ for men } & $\geq 12$ et $<13$ & 1 \\
\hline & $\geq 10$ et $<12$ & 3 \\
\hline & $<10$ & 6 \\
\hline \multirow[t]{2}{*}{ Hemoglobin (g/L) for women } & $\geq 10$ et $<12$ & 1 \\
\hline & $<10$ & 6 \\
\hline \multirow[t]{3}{*}{ Systolic blood pressure $(\mathrm{mmHg})$} & $\geq 100$ et $<109$ & 1 \\
\hline & $\geq 90$ et $<100$ & 2 \\
\hline & $<90$ & 3 \\
\hline \multirow[t]{5}{*}{ Other markers } & pulse $\geq 100$ & 1 \\
\hline & Melena & 1 \\
\hline & Syncope & 2 \\
\hline & Hepatic disease & 2 \\
\hline & Cardiac failure & 2 \\
\hline
\end{tabular}

A total score more than 8 carries high risk justifying ICU admission. From Blatchford O, Lancet 2000. scores were calculated. The median defined agreement between the experts when it was between 1 and 3, disagreement between 7 and 9 and indecision between 4 and 6 . The agreement, disagreement, or indecision was "strong" if the confidence interval was within one of three ranges: (1-3), (4-6), or (7-9) and "weak" if the confidence interval straddled two ranges. In the absence of strong agreement, the recommendations were reformulated and again scored with a view to achieving a better consensus. Three rounds of scoring were therefore performed.

\section{Area 1: Management of Gl bleeding before endoscopic diagnosis}

1. Nasogastric intubation may help confirm, but cannot discount, suspected upper GI bleeding (strong agreement).

Upper GI bleeding should always be diagnosed by esophagogastroduodenoscopy (EGD) [2,10]. Pending endoscopy, insertion of a nasogastric tube can guide the diagnostic approach, notably in a setting of acute anaemia or hemorrhagic shock. Three recently compiled retrospective analyses assessed the capacity of nasogastric aspiration to differentiate an upper from a lower source of GI bleeding [11]. Apart from one study, the design of which probably generated a high proportion of false positives, insufficient negative predictive values were reported (61\%; 95\% CI 53-68 and 64\%; 95\% CI 43-80), albeit associated with very satisfactory positive predictive values (81\%; 95\% CI 69-90 and 93\%; 95\% CI 81-98) [11].

2. Suspected rupture of esophageal/gastric varices probably does not contraindicate nasogastric intubation (strong agreement). 
The hemorrhagic risk associated with nasogastric tube insertion when rupture of esophageal varices is suspected is unknown. In a population admitted to hospital because of rupture of esophageal varices in approximately $35 \%$ of cases, gastric lavage after nasogastric tube placement was compared with intravenous erythromycin for GI endoscopy preparation [12]. There was no between-group difference in rebleeding frequency or in the number of transfused blood units [12].

3. To ensure emptying of the stomach content before EGD, intravenous erythromycin should be administered at a dose of $250 \mathrm{mg}$ ( $5 \mathrm{mg} / \mathrm{kg}$ in children), in the absence of contraindications (strong agreement).

4. If a nasogastric tube has been inserted, gastric lavage to empty the stomach is an alternative to administration of erythromycin (weak agreement).

In a recent meta-analysis, the use of a prokinetic agent (erythromycin or metoclopramide) was associated with reduced need for a repeat EGD (odds ratio [OR] 0.55; 95\% CI 0.32-0.94) [13].In contrast, there was no improvement in the length of hospital stay, the need for surgery, or the number of transfused blood units [13]. Erythromycin is useful in bleeding ulcer and in bleeding associated with portal hypertension $[14,15]$. Last, a recent study found no difference between erythromycin, gastric lavage, and the two combined in term of conditions for endoscopy [12]. Nasogastric intubation was, however, often poorly tolerated and caused pain [12].

5. In adults, the Rockall score and the GlasgowBlatchford bleeding score can probably help to identify patients at high risk of morbidity and mortality and to refer them to an intensive care unit (strong agreement).

The Rockall score and the Glasgow-Blatchford bleeding score, which have been validated in many studies [16,17], were developed for early identification of high-risk patients needing intensive care and of low-risk patients who can be discharged early. The Rockall score (Table 2) comprises clinical, biochemical, and endoscopic data and is correlated with the risk of rebleeding [18]. The Glasgow-Blatchford bleeding score (Table 3) includes clinical and biochemical data, but not EGD, and is useful to predict the need for intervention (hospitalization, transfusion, surgery) or death [19].

6. EGD should be done in the $24 \mathrm{~h}$ following the admission of a patient with suspected upper GI bleeding (strong agreement).

7. EGD probably should be done in the $12 \mathrm{~h}$ following the admission of the patient with suspected esophageal/gastric variceal bleeding (strong agreement).

8. EGD probably should be done as soon as possible, and once the patient is resuscitated, when active upper GI bleeding is suspected (strong agreement).

EGD within $24 \mathrm{~h}$ after admission of a patient with suspected upper GI bleeding reduces transfusion requirement, second-look endoscopy, and emergency surgery $[2,10,20]$. However, the influence of this 24-h interval on mortality remains controversial [2,10,20]. Earlier EGD (within 6 to $12 \mathrm{~h}$ ) is subject to debate. A meta-analysis of three randomized trials [2] showed no benefit of early endoscopy in terms of mortality, rebleeding, or need for surgery. In high-risk patients, however, early endoscopy may prove valuable. One study showed that early endoscopy in patients with blood in gastric aspirates was associated with reduced transfusion requirement and reduced hospital stay [21]. Another study identified independent predictors of benefits of early EGD that included fresh blood in gastric aspirates, hemodynamic instability, and hemoglobin $<8 \mathrm{~g} / \mathrm{dL}$ [22]. A recent study showed that when the Glasgow-Blatchford score was $\geq 12$, the mortality of patients in whom endoscopy was performed within the first $13 \mathrm{~h}$ was lower than in those who underwent endoscopy after $13 \mathrm{~h}$ [23]. Lastly, when esophageal/ gastric variceal bleeding is suspected, EGD in the first $12 \mathrm{~h}$ is usually recommended $[5,24]$.

9. In massive hematochezia and/or with hemodynamic consequences, an EGD should be performed as soon as possible (strong agreement).

Approximately $10 \%$ of cases of massive hematochezia are related to upper GI bleeding, thus justifying EGD before colonoscopy [25]. When the upper GI endoscopic findings are normal, the question sometimes arises whether to repeat EGD before colonoscopy. EGD need not be repeated if no blood is found in the upper GI tract on a first examination performed in good conditions [26].

10. In adults, in massive hematochezia and/or with hemodynamic consequences, an abdominal CT

Table 4 Forrest classification

\begin{tabular}{lll}
\hline & Class & Risk of rebleeding \\
\hline Clean base & Ill & low \\
\hline Hematin covered flat spot & Ic & low \\
\hline Adherent clot & Ilb & high \\
\hline Visible vessel & lla & high \\
\hline Oozing hemorrhage & lb & high \\
\hline Spurting hemorrhage & la & high \\
\hline
\end{tabular}

From Laine L, New Engl J Med 1994. 
angiography should be performed in emergency, if EGD is not rapidly available and/or if an aortoenteric fistula is suspected (strong agreement).

Several studies have shown the great value of abdominal CT angiography in topographic diagnosis of upper or lower GI bleeding [27-29]. Improved CT angiography techniques also can be used for etiological diagnosis and to guide treatment $[29,30]$. CT angiography enables timely recognition of the rare aortoenteric fistulas [31].

11. In children, in massive hematochezia and/or with hemodynamic consequences, and when GI endoscopic findings are normal, an emergency scintigraphy to search for a Meckel's diverticulum should be used and/or a surgical exploration (McBurney's incision or coelioscopy) (strong agreement).

In children, massive hematochezia is infrequent and mostly caused by variceal rupture in a setting of portal hypertension or Meckel's diverticulum. More rarely, vascular malformations of the colon or small intestine are observed [32]. If the GI endoscopic findings are normal, thus discounting rupture of varices, scintigraphy or even surgical exploration should be performed to search for a Meckel's diverticulum [33].

12. Vasoactive treatment (terlipressin or somatostatin or a somatostatin derivative) should be administered as soon as possible when portal hypertension is the suspected cause of GI bleeding (strong agreement).

Vasoactive medication will stop bleeding in $75 \%$ to $80 \%$ of cases [24]. A literature analysis suggests that once portal hypertension is clinically suspected, including at the prehospital management phase, vasoactive medication improves the quality of patient transport and then of the EGD [5,34]. Two drug classes are available: vasopressin derivatives (in particular terlipressin) and synthetic derivatives of somatostatin (octreotide, vapreotide). Comparison of somatostatin with terlipressin showed similar first bleeding, rebleeding, and mortality rates [35]. Combined with endoscopic therapy, octreotide significantly reduces rebleeding in comparison with placebo [36-38]. Lastly, octreotide was better than vasopressin [39] and equivalent to terlipres$\sin [40]$.

13. In a patient already treated with noradrenaline, specific vasoactive treatment of the splanchnic area (terlipressin, somatostatin, somatostatin derivative) should probably be administered when portal hypertension is the suspected cause of GI bleeding (expert opinion, weak agreement).

14. Specific vasoactive treatment of the splanchnic area (terlipressin, somatostatin, somatostatin derivative) should probably not be administered when portal hypertension is not the suspected cause of GI bleeding (weak agreement).

A 1997 meta-analysis showed that somatostatin treatment had benefits in a setting of upper GI bleeding unrelated to portal hypertension [41]. The comparison was, however, made with an $\mathrm{H}_{2}$ receptor antagonist and a placebo [41] and no study has examined this question since the advent of PPIs.

15. In GI bleeding potentially caused by ulcers, PPI treatment should be started without waiting for endoscopic diagnosis (weak agreement).

16. In GI bleeding potentially caused by ulcers, high-dose PPI treatment should probably be administered (weak agreement).

A recent meta-analysis showed that PPIs at "standard" doses (compared with no treatment, placebo, or an $\mathrm{H}_{2}$ receptor antagonist) administered beforehand facilitated EGD by reducing the proportion of patients with stigmata of recent hemorrhage or active bleeding and by reducing requirement for endoscopic therapy [42]. One study showed that before endoscopic therapy, the administration "high" PPI doses, compared with placebo, reduced transfusion requirement, rebleeding, and hospital stay [43]. This question has not been examined by comparing "high" and "standard" doses.

\section{Area 2: Treatment of upper GI bleeding unrelated to portal hypertension}

1. In the presence of stigmata associated with a low risk of rebleeding (Forrest type IIc and III), endoscopic hemostasis should not be used (strong agreement).

The natural history of ulcer disease shows a rebleeding rate of approximately $5 \%$ only in the case of Forrest type IIc or III (Table 4) [44].

2. In the presence of stigmata associated with a low risk of rebleeding (Forrest type IIc and III), PPI treatment at "standard" doses should be continued (strong agreement).

PPIs at "standard" doses have proven effective in peptic ulcer and recent French recommendations reiterate that there is no difference between the five available PPIs 
(esomeprazole, lansoprazole, omeprazole, pantoprazole, rabeprazole) [45].

3. In the presence of stigmata associated with a high risk of rebleeding (Forrest type Ia, Ib, IIa), endoscopic hemostasis should be performed (strong agreement).

A meta-analysis confirmed that endoscopic therapy reduces rebleeding risk (Forrest type Ia, Ib, IIa) compared with intravenous PPIs alone (OR 0.56; 95\% CI 0.34-0.92) [46]. Another meta-analysis confirmed the value of endoscopic therapy in this high-risk population by showing that PPI treatment only reduces mortality if endoscopic therapy has been done [47]. Lastly, the literature recommends combined endoscopic therapy (epinephrine + clips or thermal devices) and not epinephrine alone [48].

4. In the presence of an adherent clot (Forrest type IIb), endoscopic hemostasis is possible when the clot is small (strong agreement).

The usual approach to an adherent clot is to seek to dislodge it by irrigation. When the clot is resistant to washing, reported rebleeding rates range from 0\% [49] to $35 \%$ [50]. Two meta-analyses showed no advantage of endoscopic therapy over medical therapy $[48,51]$. In contrast, no data suggestan excess risk related to endoscopic therapy and a systematic review showed a low incidence of complications [52].

5. In the presence of stigmata associated with a high risk of rebleeding (Forrest type Ia, Ib, IIa, IIb), PPI treatment should be continued at "high" doses for $72 \mathrm{~h}$ (strong agreement).

PPIs have been proposed to prevent early rebleeding after spontaneous or endoscopic hemostasis and several studies suggest they are beneficial at "high" doses (according to the regimen initially proposed with intravenous omeprazole: $80 \mathrm{mg}$ in $30 \mathrm{~min}$, then $8 \mathrm{mg} / \mathrm{h}$ for $72 \mathrm{~h}$ ). The first quality study showed that PPIs at "high" doses, compared with placebo, significantly reduced the risk of recurrent bleeding (hazard ratio 3.9; 95\% CI 1.7-9), but no difference in need for surgery or death [53]. A meta-analysis showed that PPI treatment with or without endoscopic therapy, compared with placebo or an $\mathrm{H}_{2}$ receptor antagonist, reduced the risk of rebleeding (OR 0.45 ; 95\% CI $0.36-0.57$ ) and the need for surgery (OR 0.56; 95\% CI 0.45-0.7), but not mortality [54]. Complementary analyses showed that in patients with active bleeding or visible blood vessels who were receiving hemostatic treatment, a high intravenous dose of PPI reduced rebleeding, surgery, and also mortality (OR 0.57; 95\% CI 0.34-0.96) [54]. Two meta-analyses showed no effect on mortality of lower doses of PPI [48,54]. Lastly, a randomized study [55] of esomeprazole (80 $\mathrm{mg}$ then $8 \mathrm{mg} / \mathrm{h}$ for $72 \mathrm{~h}$ ) compared with placebo in patients with peptic ulcer bleeding (Forrest type Ia to IIb) who received endoscopic therapy showed a significant reduction in recurrent bleeding at $72 \mathrm{~h}$ (5.9\% vs. 10.3\%) and for up to 30 days [55]. In contrast, there was no advantage to the use of esomeprazole in terms of surgery or all-cause mortality rate [55]. A recent meta-analysis (7 randomized studies, 1,157 patients) comparing high-dose PPI (80 mg of omeprazole or pantoprazole then $8 \mathrm{mg} / \mathrm{h}$ for $72 \mathrm{~h}$ ) with non-high-dose PPI found no difference in the rates of rebleeding, surgical intervention, or mortality [56]. The study did, however, have several limitations: the analysis was not intention to treat, studies of insufficient power were included, and quite high doses of PPI were in fact administered in the non-high-dose groups. Lastly, costeffectiveness analyses showed that high-dose PPIs were beneficial after successful endoscopic hemostasis [17,57].

\section{Second-look EGD should not be done routinely} (strong agreement).

7. Second-look EGD probably should be done when a high-risk stigmata has been observed (weak agreement).

Second-look EGD is scheduled for 16 to $24 \mathrm{~h}$ after the initial endoscopy. A 2010 meta-analysis evaluated the value of second-look endoscopy with thermal coagulation or injection of adrenaline [58]. Thermal coagulation reduced recurrent bleeding $(4.2 \%$ vs. $15.7 \%$, relative risk 0.29; 95\% CI $0.11-0.73$ ) but had no effect on need for surgery or mortality. Second-look endoscopy with injection of adrenaline was not associated with any benefit. A meta-analysis done for the 2010 international consensus conference [2] suggested that second-look endoscopy reduces the risk of rebleeding (OR 0.59; 95\% CI 0.380.91 ) and surgery (OR $0.43 ; 95 \%$ CI $0.19-0.96$ ), but not mortality. Second-look endoscopy reduced rebleeding by $33 \%(p=0.03)$ in a study in which $47 \%$ of the patients were in a state of shock [59]. Saeed et al. showed in patients at high hemorrhagic risk according to the Forrest classification, a reduction in rebleeding from $24 \%$ to $0 \%(p<0.05)$ [60]. Two meta-analyses showed a significant reduction in hemorrhagic risk (respectively, relative risk 0.29 and OR 0.59 ) in at-risk patients [46,61]. The cost-effectiveness ratio of a strategy involving routine second-look EGD has not yet been assessed.

8. Patients with ulcer bleeding should not be treated with $\mathrm{H}_{2}$ receptor antagonists (strong agreement).

A 1985 meta-analysis of 27 studies of $\mathrm{H}_{2}$ receptor antagonists suggested that they marginally reduced 
mortality and surgery, in particular in patients with a gastric ulcer [62]. This was confirmed by a more recent meta-analysis [63]. Following the June 16, 2011 meeting of the French Transparency Commission, it was concluded that $\mathrm{H}_{2}$ receptor antagonists are of little therapeutic benefit in peptic ulcer-related bleeding.

9. In adults, in case of Forrest type Ia and Ib, first-intention selective arterial embolization by interventional radiology should probably be used following failure of endoscopic therapy (weak agreement).

10. In adults, in case of Forrest type Ia and Ib and catastrophic bleeding, first-intention surgical hemostasis should probably be used following failure of endoscopic therapy if local conditions do not allow arterial embolization (strong agreement).

If endoscopic therapy fails, percutaneous transcatheter arterial embolization is an alternative to surgery, notably in patients at a high surgical risk. A recently published analysis of 35 studies and 927 patients showed that the technical and clinical success rates of embolization ranged from $52 \%$ to $100 \%$ and $44 \%$ to $100 \%$, respectively [64]. Rebleeding was observed in 0 to $55 \%$ of cases depending on the study. Successful embolization improved survival 13.3-fold [64]. Retrospective comparisons between surgery and embolization showed equivalent clinical success and mortality, although embolization was applied to an older population with a higher prevalence of comorbidities [64].

11. Biopsy screening for Helicobacter pylori infection can be performed during the first EGD for GI bleeding without worsening the bleeding (strong agreement).

No study has evaluated the hemorrhagic risk linked to gastric biopsy during upper GI bleeding. In a prospective, case-control study, gastric biopsies were performed to screen for Helicobacter pylori in 324 patients with GI bleeding and 164 patients with uncomplicated ulcer [65]. The hemorrhagic risk in the group admitted for GI bleeding was not increased [65]. However, the sensitivity of the rapid urease test was significantly lower in this group (false-negative $16.7 \%$ vs. $5.6 \%$ ) [65].

12. There is probably no advantage to emergency treatment of Helicobacter pylori infection in the case of GI ulcer bleeding (strong agreement).

A meta-analysis clearly established that eradication therapy of Helicobacter pylori infection compared with "conventional" (OR 0.17; 95\% CI 0.1-0.32) or "prolonged" (OR 0.25; 95\% CI 0.08-0.76) antisecretory therapy, reduced the long-term (1 year or more) risk of recurrent bleeding [66]. In contrast, no study has shown that eradication therapy is useful in early rebleeding.

13. Aspirin antiplatelet therapy should probably be maintained in the case of GI ulcer bleeding until consultation with specialists (weak agreement).

14. In dual antiplatelet therapy, clopidogrel should probably be stopped in the case of ulcer bleeding until consultation with specialists (strong agreement).

A meta-analysis showed that discontinuing or not adhering to aspirin given preventively was associated with a threefold higher risk of major adverse cardiac events [67]. Stoppage of antiplatelet treatment in a hemorrhagic setting probably yields no immediate benefit because an antithrombotic effect persists for 7 to 10 days [68]. A randomized study in patients with aspirin-induced peptic ulcer suggested that early reintroduction of aspirin or clopidogrel was possible [69]. Another randomized study in 156 patients with aspirin-induced ulcer bleeding who received endoscopic therapy and PPI treatment showed that immediate reintroduction of aspirin was associated with a twofold higher risk, albeit not statistically significant, of rebleeding [70]. Conversely, discontinuation of aspirin was associated with a significant increase in mortality at 8 weeks [70].

\section{Area 3: Treatment of upper GI bleeding related to portal hypertension}

1. Endoscopic therapy of bleeding esophageal/gastric varices should be done during initial EGD (strong agreement).

2. Endoscopic therapy of bleeding esophageal varices is based on band ligation. Sclerotherapy is an alternative in the very young child (strong agreement).

3. Endoscopic therapy of bleeding gastric varices is based on obturation with tissue adhesives (strong agreement).

EGD is the key examination in management of GI bleeding in cirrhotic patients [5]. No study indicates the best timing, but international recommendations advise as soon as possible (within $12 \mathrm{~h}$ ) in a resuscitated patient [5]. It is now clear that the treatment of choice in esophageal varices is band ligation, which controls active bleeding and reduces the rebleeding rate with fewer adverse effects than sclerosis [71]. Obturation using cyanoacrylate glue, which is technically more difficult than 
ligation, is the reference treatment of bleeding gastric varices [72].

4. Vasoactive treatment (terlipressin or somatostatin or somatostatin derivative) should be continued for 3 to 5 days after endoscopic therapy of esophageal/gastric varices rupture (strong agreement).

Combined (vasoactive and endoscopic) treatment is more effective than endoscopic therapy in controlling bleeding from esophageal/gastric varices. No clear reduction in mortality by a combined treatment has been demonstrated. The length of vasoactive treatment has not been evaluated in dedicated trials. Sung et al. observed significantly less recurrent bleeding at $48 \mathrm{~h}$ in patients treated by ligation and octreotide compared with in those treated by ligation alone [37]. The combination of sclerotherapy and somatostatin for 5 days was more effective than sclerotherapy alone [73]. Besson et al. combined sclerotherapy and octreotide $(25 \mu \mathrm{g} / \mathrm{h})$ for 5 days and observed increased survival without rebleeding 5 days after sclerotherapy [36]. In another study, survival without rebleeding at 5 days was greater in the group of patients treated with endoscopy and vapreotide than in the group treated with endoscopy and placebo [74].

5. In adults, after endoscopic hemostasis of bleeding related to portal hypertension, the placement of a transjugular intrahepatic portosystemic shunt (TIPS) within $72 \mathrm{~h}$ should be considered in high-risk patients (Child-Pugh class B with active bleeding and Child-Pugh class C) (strong agreement).

Two studies showed that early placement of TIPS reduces the risk of failure to control bleeding and rebleeding in patients at high risk of recurrence [75,76]. In the more recent study, high-risk patients were defined as Child-Pugh class B patients with persistent bleeding at the time of EGD or Child-Pugh class C patients [76]. Improvement of survival following TIPS placement also was demonstrated compared with the control group (13\% vs. $39 \%)$ [76].

6. Esophageal/gastric balloon tamponade should be considered after failure of endoscopic therapy pending radical treatment of portal hypertension. In children, its use should probably be envisaged if emergency EGD is not possible (strong agreement).

The Sengstaken-Blakemore tube (with two balloons for esophageal varices) and the Linton-Nachlas tube (single balloon for gastric cardia varices or fundal varices) were tested in a 1988 old studies for tamponade of bleeding varices. The success rate was $40 \%$ to $90 \%$, but there were numerous complications (inhalation lung disease, esophageal ulceration, and rupture) and rebleeding occurred in approximately one of two cases [77].

7. Antibiotic prophylaxis with third-generation cephalosporin or with fluoroquinolone for 5 to 7 days should be given to any cirrhotic patient with GI bleeding (strong agreement).

A bacterial infection is noted in approximately $40 \%$ of cirrhotic patients in the 7 days following their admission for upper GI bleeding [78]. These infections are independently associated with the risk of rebleeding and with mortality [79]. A meta-analysis has clearly established that prophylactic antibiotic therapy significantly reduces infection (by 32\%; 95\% CI 22-42) and death (by 9\%; 95\% CI 2.9-15.3) [80]. The oral administration of a quinolone is recommended in most patients [5,81]. Intravenous quinolone is possible if the oral route is not available. A recent study in a population of patients with advanced cirrhosis (Child-Pugh class B or C) showed that intravenous ceftriaxone was associated with a lower infection rate than oral norfloxacin [82]. International recommendations state that intravenous ceftriaxone should be considered as prophylactic antibiotic therapy in this population [5].

8. Lactulose treatment to prevent hepatic encephalopathy should probably not be initiated during GI bleeding in a cirrhotic patient (expert opinion, strong agreement).

9. In adults, PPI therapy should not be initiated or continued when EGD has confirmed a diagnosis of ruptured esophageal/gastric varices (strong agreement).

10. In children, PPI therapy should probably be initiated or continued in case of esophageal/gastric varices rupture (weak agreement).

Esophageal ulceration is a possible complication of variceal ligation. In a randomized, controlled trial, PPI therapy reduced the size, but not the number, of postligation ulcers [83]. Several retrospective studies suggest that PPIs may increase the risk of bacterial infection in this population [84]. In children, however, gastritis is frequently associated with portal hypertension [85].

11. One objective of hemodynamic treatment during esophageal/gastric varices rupture should be to restore a satisfactory mean blood pressure to preserve tissue perfusion (strong agreement).

12. In adults, during esophageal/gastric varices rupture, early hemodynamic treatment should 
probably maintain mean blood pressure at approximately $65 \mathrm{mmHg}$ in most patients (strong agreement).

In cirrhosis, portal pressure seems to be related linearly to plasma volume and may affect the severity of bleeding [86]. The target mean blood pressure is not well known in this population. On the basis of extrapolation of recommendations established for hemorrhagic shock in trauma patients [87], but also for septic shock [88], a mean blood pressure of approximately $65 \mathrm{mmHg}$ can be proposed.

13. Blood transfusion in most patients should probably target a hemoglobin concentration of 7 to $8 \mathrm{~g} / \mathrm{dL}$ (strong agreement).

The target hemoglobin concentration in esophageal/ gastric varices rupture is not clearly defined. In trauma patients with hemorrhagic shock, a target hemoglobin concentration of 7 to $9 \mathrm{~g} / \mathrm{dL}$ has been proposed [87]. Restricted blood transfusion (hemoglobin concentration 7 to $8 \mathrm{~g} / \mathrm{dL}$ ) also is recommended in the specific context of GI bleeding related to portal hypertension [5].

14. In GI bleeding in patients with cirrhosis, there is probably no indication for administration of freshfrozen plasma with the objective to correct a coagulopathy (strong agreement).

15. In GI bleeding in patients with cirrhosis, there is no indication for administration of fresh-frozen plasma before EGD (strong agreement).

In hemorrhagic shock due to trauma, early treatment with fresh-frozen plasma is recommended when bleeding is massive [87] but is much debated in cirrhotic patients [5]. An association between this type of transfusion and the risk of excessive plasma volume increase and worsening of portal hypertension has been suggested [10]. Lastly, prothrombin time and international normalized ratio are not good indicators for coagulability in patients with cirrhosis and attempts to correct them are therefore not recommended [5].

16. In GI bleeding in patients with cirrhosis, there is no indication for the administration of factor VIIa (strong agreement).

A recent randomized trial in patients with cirrhosis and variceal bleeding found no difference between factor VIIa and placebo in terms of control of bleeding or survival [89].

17. In GI bleeding in patients with cirrhosis, platelet transfusion should probably be considered when bleeding is uncontrolled and platelet count is $<30,000 / \mathrm{mm}^{3}$ (strong agreement).

Platelet transfusion in severe bleeding is usually recommended when platelet count is $<50,000 / \mathrm{mm}^{3}[87,90]$. No study has examined this question in the particular setting of GI bleeding in the cirrhotic patient. The risk of worsening portal hypertension has been raised [10]. Thrombocytopenia is common in the cirrhotic patient and is a poor indicator of hemorrhagic risk [5]. On the basis of these arguments, a transfusion is usually recommended for a platelet count $<30,000 / \mathrm{mm}^{3}$ but should not delay endoscopy $[5,10]$.

18. In adults, in esophageal/gastric bleeding, beta-blocker treatment should be started when vasoactive treatment is discontinued (strong agreement).

Secondary prophylaxis of bleeding from esophageal/ gastric varices is based on the combination of noncardioselective beta-blockers and repeated ligation [5]. Early introduction of beta-blockers seems to avoid a rebound effect of portal hypertension favoring rebleeding. A recent meta-analysis of 23 studies showed that combined treatment (beta-blocker and ligation) significantly reduced rebleeding in comparison with endoscopic therapy alone (OR 0.68 ; 95\% CI $0.52-0.89$ ) or pharmacological treatment alone (OR 0.71; 95\% CI 0.59-0.86) [91]. The median interval to introduction of beta-blockers was 3 (range $1-7$ ) days [91].

19. After ligation of esophageal varices, nasogastric intubation should probably be avoided (expert opinion, strong agreement).

\section{Area 4: Management of presumed lower GI bleeding}

1. In adults with massive hematochezia, demonstration of active bleeding by abdominal CT angiography or arteriography justifies embolization as first-line therapy (strong agreement).

After angiographic localization of bleeding, the hemostatic efficacy of embolization is approximately $90 \%$. One study showed, however, that embolization was associated with an approximately $10 \%$ risk of recurrent bleeding and more rarely a risk of colonic ischemia [92]. In approximately $5 \%$ of cases, embolization was technically impossible [92].

2. In massive hematochezia, and in the absence of detectable bleeding on abdominal CT angiography or arteriography (or scintigraphy in children), a 
prepared colonoscopy should be performed within $24 \mathrm{~h}$ (strong agreement).

3. In massive and persistent hematochezia, and in the absence of detectable bleeding on abdominal CT angiography or arteriography, a prepared colonoscopy should probably be done within $12 \mathrm{~h}$ with the objective of performing endoscopic hemostasis (strong agreement).

Colonoscopy identifies the cause of hematochezia in approximately $75 \%$ of cases [93]. Colonoscopy after preparation is therefore recommended within $24 \mathrm{~h}$ $[25,94]$. If hematochezia persists, colonoscopy within a shorter timeframe $(12 \mathrm{~h})$ should be considered, notably with a view to hemostatic treatment [95-100]. Initial endoscopic hemostasis is successful in nearly 95\% of cases $[93,94,101,102]$. In contrast, the results in terms of definitive hemostasis vary from one study to another. In all these studies the risk of complications of colonic endoscopic hemostasis was low or zero.

4. In adults with massive hematochezia, rectosigmoidoscopy probably should be done if full colonoscopy cannot be performed within $24 \mathrm{~h}$ (strong agreement).

In the $80 \%$ of cases when bleeding ceases spontaneously, a prepared colonoscopy should be performed as soon as possible [103]. Early colonoscopy increases the chances of identifying the cause of bleeding and of proposing endoscopic hemostasis $[93,95,96,98,99]$. In contrast, the prognostic value of early colonoscopy seems more questionable [96]. Rectosigmoidoscopy, often performed in imperfect conditions in terms of preparation and safety, rarely dispenses with the need for full colonoscopy $[25,94]$.

5. When lower GI bleeding is massive, surgical hemostasis should be proposed in case of arterial embolization or colonoscopy failure or rebleeding (strong agreement).

6. When lower GI bleeding is catastrophic, surgical hemostasis should be performed if arterial embolization is not possible under local conditions (strong agreement).

The indications for surgical hemostasis have been considerably reduced because of advances in embolization and in endoscopic therapy and are limited to failure of embolization or of colonoscopy or of both [25,94]. Such situations essentially concern diverticular bleeding. If there is an indication for surgery, an attempt should be made to determine the site of bleedingin order to adapt the surgical procedure. When the site of bleeding is known with certainty, partial colectomy should be performed. In diffuse colonic diverticulosis when the site of bleeding is unidentified, subtotal colectomy should be preferred.

7. In massive or persistent lower GI bleeding, the small intestine should be examined as soon as possible when CT angiography and colonoscopy fail to locate the source of bleeding (strong agreement).

When the cause of bleeding is unknown, small intestine involvement should be considered whenever terminal ileoscopy (which should be routine during colonoscopic examination of lower GI bleeding) reveals blood or mucosal anomalies [104]. Etiological diagnosis of small intestine bleeding often is difficult [105]. Endoscopic techniques (capsule endoscopy, enteroscopy) usually enable diagnosis [105]. The data on endoscopic hemostasis of bleeding in the colon can be transposed to small intestine lesions accessible to endoscopy, albeit with a probably higher risk of complications.

\section{Area 5: Prevention of upper Gl bleeding in intensive care}

1. Patients with a history of peptic ulcer admitted to intensive care probably should be considered at risk of GI bleeding (strong agreement).

A 1983 retrospective analysis of patients admitted to medical-surgical intensive care unit defined a risk score for upper GI bleeding in intensive care as the sum of coefficients associated to 24 risk factors [106]. A history of ulcers was associated with the most determinant coefficient [106], a result confirmed by another study [107]. It also should be emphasized that patients with a peptic ulcer within the previous month or year often are excluded from studies that analyze upper GI bleeding in intensive care $[108,109]$.

2. Early enteral feeding is effective in preventing "stress ulcer" bleeding (strong agreement).

3. Patients requiring mechanical ventilation for more than $48 \mathrm{~h}$ and for whom enteral feeding is not possible should be considered to be at risk of "stress ulcer" bleeding (strong agreement).

4. Patients admitted to intensive care with kidney failure and/or coagulopathy and/or receiving antiplatelet therapy should be considered to be at risk of "stress ulcer" bleeding (strong agreement).

5. Routine drug prophylaxis of "stress ulcer" should not be used in intensive care patients with enteral feeding (strong agreement). 
6. Ulcer prophylaxis medication should probably be given routinely in intensive care patients with a history of peptic ulcer (even if enterally fed) (weak agreement).

7. Ulcer prophylaxis medication probably should be given routinely to intensive care patients receiving antiplatelet therapy (even if enterally fed)

(weak agreement).

8. In the absence of enteral feeding, ulcer prophylaxis medication should probably be given to ventilated patients (weak agreement).

9. In the absence of enteral feeding, ulcer prophylaxis medication should probably be given to patients with coagulopathy (weak agreement).

Several criteria, including mechanical ventilation [109-111], coagulopathy [109,110], kidney failure [111], and lack of enteral feeding [111], have been identified as risk factors, sometimes independent, for upper GI bleeding in intensive care. In 174 patients, mechanical ventilation for more than 5 days and coagulopathy (defined by platelet count $<50000 / \mathrm{mm}^{3}$, effective anticoagulation or lengthening of the partial thromboplastin time) were the risk factors most strongly associated with upper GI bleeding [110]. In a vast prospective and multicenter analysis in 2,252 patients, Cook et al. identified mechanical ventilation of more than $48 \mathrm{~h}$ (OR 15.6) and coagulopathy (OR 4.3) as the only two risk factors independently associated with upper GI bleeding [109]. The incidence of bleeding was $8.4 \%$ in the presence of these two risk factors and only $0.1 \%$ in their absence [109]. Some years later, the same team in a randomized, multicenter trial in 1,077 mechanically ventilated patients compared two ulcer prophylactic drugs (ranitidine and sucralfate) and identified a risk factor independent of upper GI bleeding-peak creatinine (by $100 \mu \mathrm{mol} / \mathrm{L}$ increments, OR 1.16; 95\% CI 1.02-1.32)-and two protective factors-enteral feeding (OR 0.3; 95\% CI 0.130.67 ) and administration of ranitidine (OR 0.39; 95\% CI 0.17-0.83) [111].

10. In children, a pediatric risk of mortality score (PRISM) >10 associated with respiratory failure or coagulopathy or both probably calls for ulcer prophylaxis (strong agreement).

Pediatric data enabling analysis of the benefits of prophylactic treatment of "stress ulcer" bleeding are rare [112]. A 1998 prospective study in 881 children identified 3 risk factors independent of clinically significant upper GI bleeding acquired in intensive care: respiratory failure (OR 2.87; 95\% CI 1.3-82.8). coagulopathy (OR 9.3; 95\% CI 2.8-30.3), and a pediatric risk of mortality score $\geq 10($ OR 13.4; 95\% CI 3.7-47.9) [113]. The presence of two or more factors was associated with an approximately $90 \%$ incidence of GI bleeding. This study confirms other data identifying mechanical ventilation, lung disorders, and thrombocytopenia as risk factors for GI bleeding [114-116].

\section{Screening for Helicobacter pylori should not be routine in intensive care patients (strong agreement).}

The prevalence of Helicobacter pylori infection in intensive care is greater than that in a control population [117]. However, there are few arguments to suggest that Helicobacter pylori is responsible for upper GI bleeding in intensive care. Three studies have reported a statistical link between Helicobacter pylori infection and stress-related GI bleeding [118-120]. Data from two of them differ according to the tests used to diagnose Helicobacter pylori infection [118,119]. By coupling several diagnostic methods (serology, biopsy, enzyme immunoassay detection of antigen in stools), Maury et al. found a significantly greater incidence of Helicobacter pylori infection in the case of GI bleeding (36\% vs. 16\%) [120]. However, this study was conducted in only 25 patients [120]. Lastly, three other studies found no correlation between Helicobacter pylori infection and "stress ulcer" bleeding $[117,121,122]$.

12. A nasogastric tube should probably be removed once it is no longer used (expert opinion, strong agreement).

13. A large bore nasogastric tube for aspiration should probably be replaced by a small-calibre enteral tube as soon as possible (expert opinion, strong agreement).

14. Antacids should not be used to prevent "stress ulcer" bleeding (strong agreement).

15. $\mathrm{H}_{2}$ receptor antagonists and PPIs are probably comparable but of low efficacy in preventing "stress ulcer" bleeding (weak agreement).

16. $\mathrm{H}_{2}$ receptor antagonists and PPIs are probably comparable regarding the risk ventilator-associated pneumonia during mechanical ventilation (strong agreement).

In the prevention of upper GI bleeding in intensive care, $\mathrm{H}_{2}$ receptor antagonists, long used in clinical trials, are superior to placebo [3,123], antacids [123], and sucralfate [124]. A recent meta-analysis showed that $\mathrm{H}_{2}$ receptor antagonist treatment was associated with a significant reduction in the risk of GI bleeding compared with placebo (OR 0.47; 95\% CI 0.29-0.76) [3]. In contrast, this risk decrease was not observed in the subgroup of enterally fed patients (OR 1.26; 95\% CI 0.43-3.7) [3]. PPIs have not been compared with placebo in this indication. A 
randomized, controlled study in 359 mechanically ventilated patients compared a PPI (oral omeprazole) and an $\mathrm{H}_{2}$ receptor antagonist (intravenous cimetidine) in prophylaxis of upper GI bleeding in intensive care [125]. The time spent at $\mathrm{pH} \geq 6$ was significantly greater in the omeprazole group than in the cimetidine group (100\% vs. $50 \%$ per treatment day), and the prevalence of GI bleeding did not differ between the two groups. A recent meta-analysis comparing PPIs and $\mathrm{H}_{2}$ receptor antagonists confirmed this result [126] and also showed that there was no difference between PPIs and $\mathrm{H}_{2}$ receptor antagonists in terms of the risk of nosocomial pneumonia [126].

\section{Competing interests}

Scientific presentation at a symposium held on by W.L GORE: Christophe Bureau, Nicolas Carbonell, Dominique Thabut. Scientific presentation at a symposium held on by Eumédica: Dominique Pateron, Nicolas Carbonell. Participation in an observatory supported by Eumédic: Nicolas Carbonell, Dominique Thabut. Expert's report for Sanofi-Aventis and Ethypharm: Marc Bardou. All other authors declare that they have no conflicts of interest.

\section{Authors' contribution}

$\mathrm{DO}, \mathrm{MD}, \mathrm{DS}$ and $\mathrm{CG}$ participated in the design and the coordination of the study and checked compliance to the GRADE method. CG and the group of experts participated in the development and the grading of the level of proof of the recommendations. DO carried out the RAND/UCLA method for the collective scoring. DO, MD, DS, CG and the group of experts participated in the redaction of the arguments' recommendations. All authors read and approved the final manuscript.

\section{Authors' information}

'Organising Committee for the SRLF Recommendations and Assessments Board. ${ }^{2}$ Expert coordinator.

${ }^{3}$ Experts: Marc Bardou (Dijon), Sophie Branchereau (Le Kremlin-Bicêtre), Christophe Bureau (Toulouse), Nicolas Carbonel (Paris), Philippe Cluzel (Paris), Emmanuel Guérot (Paris), Pierre-François Laterre (Bruxelles), Gilles Lesur (Boulogne), Emmanuel Mas (Toulouse), Eric Maury (Paris), Stéphane Nahon (Montfermeil), Philippe Otal (Toulouse), Dominique Pateron (Paris), Gaël Piton (Besançon), Jean-Pierre Quenot (Dijon), Marika Rudler (Paris), Dominique Thabut (Paris), Pierre Tissières (Le Kremlin-Bicêtre), Patrice Valleur (Paris) SRLF Recommandations and Assessments Board: Cédric Bretonnière, Karim Chaoui, Aurélie Cravoisy, Michel Djibré, Laurent Dupic, Fabienne Fieux, Dominique Hurel, Virginie Lemiale, Olivier Lesieur, Martine Lesny, Pascal Meyer, Christophe Milési, Benoit Misset, Mehran Monchi, David Orlikowski, David Osman, Jean-Pierre Quenot, Daniel Da Silva, Lilia Soufir, Thierry Van Der Linden, Isabelle Verheyde.

\section{Author details}

'AP-HP, Hôpitaux universitaires Paris-Sud, Hôpital de Bicêtre, Service de réanimation médicale, Le Kremlin-Bicêtre, F-94270, France. ${ }^{2}$ AP-HP, Hôpitaux universitaires Est Parisien, Hôpital Tenon, Service de pneumologie et réanimation, Paris F-75020, France. ${ }^{3}$ Hôpital Delafontaine, Service de réanimation polyvalente, Saint-Denis F-93200, France. ${ }^{4}$ Hôpital Privé Jacques Cartier, Service de réanimation polyvalente, Massy F-91300, France.

Received: 11 September 2012 Accepted: 5 October 2012

Published: 9 November 2012

\section{References}

1. van Leerdam ME, Vreeburg EM, Rauws EA, Geraedts AA, Tijssen JG, Reitsma $J B$, Tytgat GN: Acute upper Gl bleeding: did anything change? Time trend analysis of incidence and outcome of acute upper Gl bleeding between 1993/1994 and 2000. Am J Gastroenterol 2003, 98:1494-1499.

2. Barkun AN, Bardou M, Kuipers EJ, Sung J, Hunt RH, Martel M, Sinclair P: International consensus recommendations on the management of patients with nonvariceal upper gastrointestinal bleeding. Ann Intern Med 2010, 152:101-113.
3. Marik PE, Vasu T, Hirani A, Pachinburavan M: Stress ulcer prophylaxis in the new millennium: a systematic review and meta-analysis. Crit Care Med 2010, 38:2222-2228.

4. Daley R, Rebuck J, Welage L, Rogers F: Prevention of stress ulceration: current trends in critical care. Crit Care Med 2004, 32:2008-2013.

5. de Franchis R: Revising consensus in portal hypertension: report of the Baveno V consensus workshop on methodology of diagnosis and therapy in portal hypertension. J Hepatol 2010, 53:762-768.

6. Raynard B, Bernard B, Bleichner G, Fagon J: Prévention des hémorragies digestives hautes de stress en réanimation. Réanim Urgences 2000 9:555-560

7. Atkins $D$, Best $D$, Briss PA, Eccles M, Falck-Ytter Y, Flottorp S, Guyatt GH, Harbour RT, Haugh MC, Henry D, et al: Grading quality of evidence and strength of recommendations. BMJ 2004, 328:1490.

8. Guyatt GH, Oxman AD, Vist GE, Kunz R, Falck-Ytter Y, Alonso-Coello P, Schunemann HJ: GRADE: an emerging consensus on rating quality of evidence and strength of recommendations. BMJ 2008, 336:924-926

9. Fitch K, Bernstein S, Aguilar M, Burnand B, LaCalle J, Lazaro P, van Het Loo M, Mc Donnell J, Vader JP, Kahan JP: The RAND/UCLA appropriateness method user's manual. Santa Monica: RAND; 2001.

10. Colle I, Wilmer A, Le Moine O, Debruyne R, Delwaide J, Dhondt E, Macken E, Penaloza A, Piessevaux H, Stephenne X, et al: Upper gastrointestinal tract bleeding management: Belgian guidelines for adults and children. Acta Gastroenterol Belg 2011, 74:45-66.

11. Palamidessi N, Sinert R, Falzon L, Zehtabchi S: Nasogastric aspiration and lavage in emergency department patients with hematochezia or melena without hematemesis. Acad Emerg Med 2010, 17:126-132.

12. Pateron D, Vicaut E, Debuc E, Sahraoui K, Carbonell N, Bobbia X, Thabut D, Adnet $F$, Nahon P, Amathieu R, et al: Erythromycin infusion or gastric lavage for upper gastrointestinal bleeding: a multicenter randomized controlled trial. Ann Emerg Med 2011, 57:582-589.

13. Barkun AN, Bardou M, Martel M, Gralnek IM, Sung JJ: Prokinetics in acute upper Gl bleeding: a meta-analysis. Gastrointest Endosc 2010, 72:1138-1145

14. Carbonell N, Pauwels A, Serfaty L, Boelle PY, Becquemont L, Poupon R Erythromycin infusion prior to endoscopy for acute upper gastrointestinal bleeding: a randomized, controlled, double-blind trial. Am J Gastroenterol 2006, 101:1211-1215.

15. Altraif I, Handoo FA, Aljumah A, Alalwan A, Dafalla M, Saeed AM, Alkhormi A, Albekairy AK, Tamim H: Effect of erythromycin before endoscopy in patients presenting with variceal bleeding: a prospective, randomized, double-blind, placebo-controlled trial. Gastrointest Endosc 2011, 73:245-250

16. Nahon $\mathrm{S}$, Nouel $\mathrm{O}$, Hagege $\mathrm{H}$, Cassan $\mathrm{P}$, Pariente $\mathrm{A}$, Combes $\mathrm{R}$, Kerjean $\mathrm{A}$ Doumet $\mathrm{S}$, Cocq-Vezilier $\mathrm{P}$, Tielman $\mathrm{G}$, et al: Favorable prognosis of uppergastrointestinal bleeding in 1041 older patients: results of a prospective multicenter study. Clin Gastroenterol Hepatol 2008, 6:886-892.

17. Barkun A, Sabbah S, Enns R, Armstrong D, Gregor J, Fedorak RN, Rahme E, Toubouti Y, Martel M, Chiba N, Fallone CA: The Canadian Registry on Nonvariceal Upper Gastrointestinal Bleeding and Endoscopy (RUGBE) Endoscopic hemostasis and proton pump inhibition are associated with improved outcomes in a real-life setting. Am J Gastroenterol 2004, 99:1238-1246.

18. Rockall TA, Logan RF, Devlin HB, Northfield TC: Risk assessment after acute upper gastrointestinal haemorrhage. Gut 1996, 38:316-321.

19. Blatchford O, Murray WR, Blatchford M: A risk score to predict need for treatment for upper-gastrointestinal haemorrhage. Lancet 2000, 356:1318-1321.

20. Spiegel BM, Vakil NB, Ofman JJ: Endoscopy for acute nonvariceal upper gastrointestinal tract hemorrhage: is sooner better? A systematic review. Arch Intern Med 2001, 161:1393-1404.

21. Lee JG, Turnipseed S, Romano PS, Vigil H, Azari R, Melnikoff N, Hsu R, Kirk D, Sokolove P, Leung JW: Endoscopy-based triage significantly reduces hospitalization rates and costs of treating upper GI bleeding: a randomized controlled trial. Gastrointest Endosc 1999, 50:755-761.

22. Adamopoulos AB, Baibas NM, Efstathiou SP, Tsioulos DI, Mitromaras AG, Tsami AA, Mountokalakis TD: Differentiation between patients with acute upper gastrointestinal bleeding who need early urgent upper gastrointestinal endoscopy and those who do not. A prospective study. Eur I Gastroenterol Hepatol 2003, 15:381-387. 
23. Lim LG, Ho KY, Chan YH, Teoh PL, Khor CJ, Lim LL, Rajnakova A, Ong TZ, Yeoh KG: Urgent endoscopy is associated with lower mortality in highrisk but not low-risk nonvariceal upper gastrointestinal bleeding. Endoscopy 2011, 43:300-306.

24. Garcia-Tsao G, Bosch J: Management of varices and variceal hemorrhage in cirrhosis. N Engl J Med 2010, 362:823-832.

25. Rockey DC: Lower gastrointestinal bleeding. Gastroenterology 2006, 130:165-171.

26. Chung YF, Wong WK, Soo KC: Diagnostic failures in endoscopy for acute upper gastrointestinal haemorrhage. Br J Surg 2000, 87:614-617.

27. Yoon W, Jeong YY, Shin SS, Lim HS, Song SG, Jang NG, Kim JK, Kang HK: Acute massive gastrointestinal bleeding: detection and localization with arterial phase multi-detector row helical CT. Radiology 2006, 239:160-167.

28. Jaeckle T, Stuber G, Hoffmann MH, Jeltsch M, Schmitz BL, Aschoff AJ: Detection and localization of acute upper and lower gastrointestinal (Gl) bleeding with arterial phase multi-detector row helical CT. Eur Radiol 2008, 18:1406-1413.

29. Duchat F, Soyer P, Boudiaf M, Martin-Grivaud S, Fargeaudou Y, Malzy P, Dray $X$, Sirol M, Hamzi L, Pocard M, Rymer R: Multi-detector row CT of patients with acute intestinal bleeding: a new perspective using multiplanar and MIP reformations from submillimeter isotropic voxels. Abdom Imaging 2010, 35:296-305.

30. Kennedy DW, Laing CJ, Tseng LH, Rosenblum DI, Tamarkin SW: Detection of active gastrointestinal hemorrhage with CT angiography: a 4(1/2)-year retrospective review. J Vasc Interv Radio/ 2010, 21:848-855.

31. Burks JA Jr, Faries PL, Gravereaux EC, Hollier LH, Marin ML: Endovascular repair of bleeding aortoenteric fistulas: a 5-year experience. J Vasc Surg 2001, 34:1055-1059.

32. de la Torre L, Carrasco D, Mora MA, Ramirez J, Lopez S: Vascular malformations of the colon in children. J Pediatr Surg 2002, 37:1754-1757.

33. Yau KK, Siu WT, Law BK, Yip KF, Tang WL, Li MK: Laparoscopy-assisted surgical management of obscure gastrointestinal bleeding secondary to Meckel's diverticulum in a pediatric patient: case report and review of literature. Surg Laparosc Endosc Percutan Tech 2005, 15:374-377.

34. Levacher S, Letoumelin P, Pateron D, Blaise M, Lapandry C, Pourriat JL: Early administration of terlipressin plus glyceryl trinitrate to control active upper gastrointestinal bleeding in cirrhotic patients. Lancet 1995, 346:865-868.

35. D'Amico G, Pagliaro L, Bosch J: Pharmacological treatment of portal hypertension: an evidence-based approach. Semin Liver Dis 1999, 19:475-505.

36. Besson I, Ingrand P, Person B, Boutroux D, Heresbach D, Bernard P, Hochain P, Larricq J, Gourlaouen A, Ribard D, et al: Sclerotherapy with or without octreotide for acute variceal bleeding. N Engl J Med 1995, 333:555-560.

37. Sung JJ, Chung SC, Yung MY, Lai CW, Lau JY, Lee YT, Leung VK, Li MK, Li AK: Prospective randomised study of effect of octreotide on rebleeding from oesophageal varices after endoscopic ligation. Lancet 1995 , 346:1666-1669.

38. Zuberi BF, Baloch Q: Comparison of endoscopic variceal sclerotherapy alone and in combination with octreotide in controlling acute variceal hemorrhage and early rebleeding in patients with low-risk cirrhosis. Am J Gastroenterol 2000, 95:768-771.

39. Hwang SJ, Lin HC, Chang CF, Lee FY, Lu CW, Hsia HC, Wang SS, Lee SD, Tsai YT, Lo KJ: A randomized controlled trial comparing octreotide and vasopressin in the control of acute esophageal variceal bleeding. J Hepatol 1992, 16:320-325.

40. Gotzsche PC, Hrobjartsson A: Somatostatin analogues for acute bleeding oesophageal varices. Cochrane Database Syst Rev 2008, 3:CD000193.

41. Imperiale TF, Birgisson S: Somatostatin or octreotide compared with $\mathrm{H} 2$ antagonists and placebo in the management of acute nonvariceal upper gastrointestinal hemorrhage: a meta-analysis. Ann Intern Med 1997, 127:1062-1071.

42. Sreedharan A, Martin J, Leontiadis Gl, Dorward S, Howden CW, Forman D, Moayyedi P: Proton pump inhibitor treatment initiated prior to endoscopic diagnosis in upper gastrointestinal bleeding. Cochrane Database Syst Rev 2010, 7:CD005415.

43. Lau JY, Leung WK, Wu JC, Chan FK, Wong WW, Chiu PW, Lee WW, Lee KK, Cheung FK, Siu P, et al: Omeprazole before endoscopy in patients with gastrointestinal bleeding. N Engl J Med 2007, 356:1631-1640.

44. Gralnek IM, Barkun AN, Bardou M: Management of acute bleeding from a peptic ulcer. N Engl J Med 2008, 359:928-937.
45. Réévaluation 2009 des médicaments inhibiteurs de la pompe à protons chez l'adulte, Haute Autorité de santé, Commission de Transparence. http://www.has-sante.fr/portail/upload/docs/application/pdf/2009-04/ argumentaire_ipp_2009-04-27_14-15-18_458.pdf

46. Barkun A, Wyse J, Romagnuolo J, Gralnek I, Bardou M: Should we be performing routine second-look endoscopy in acute peptic ulcer bleeding in 2009? A meta-analysis. Gastroenterology 2009, 134:23.

47. Leontiadis Gl, Sharma VK, Howden CW: Proton pump inhibitor treatment for acute peptic ulcer bleeding. Cochrane Database Syst Rev 2006, 1:CD002094

48. Laine L, McQuaid KR: Endoscopic therapy for bleeding ulcers: an evidence-based approach based on meta-analyses of randomized controlled trials. Clin Gastroenterol Hepatol 2009, 7:33-47. quiz 31-32.

49. Laine $L$, Stein C, Sharma V: A prospective outcome study of patients with clot in an ulcer and the effect of irrigation. Gastrointest Endosc 1996, 43:107-110

50. Jensen DM, Kovacs TO, Jutabha R, Machicado GA, Gralnek IM, Savides TJ, Smith J, Jensen ME, Alofaituli G, Gornbein J: Randomized trial of medical or endoscopic therapy to prevent recurrent ulcer hemorrhage in patients with adherent clots. Gastroenterology 2002, 123:407-413.

51. Kahi CJ, Jensen DM, Sung JJ, Bleau BL, Jung HK, Eckert G, Imperiale TF: Endoscopic therapy versus medical therapy for bleeding peptic ulcer with adherent clot: a meta-analysis. Gastroenterology 2005, 129:855-862.

52. Marmo R, Rotondano G, Piscopo R, Bianco MA, D'Angella R, Cipolletta L: Dual therapy versus monotherapy in the endoscopic treatment of high-risk bleeding ulcers: a meta-analysis of controlled trials. Am J Gastroenterol 2007, 102:279-289. quiz 469.

53. Lau JY, Sung JJ, Lee KK, Yung MY, Wong SK, Wu JC, Chan FK, Ng EK, You JH, Lee $C W$, et al: Effect of intravenous omeprazole on recurrent bleeding after endoscopic treatment of bleeding peptic ulcers. N Engl J Med 2000 343:310-316.

54. Leontiadis Gl, Sharma VK, Howden CW: Proton pump inhibitor therapy for peptic ulcer bleeding: Cochrane collaboration meta-analysis of randomized controlled trials. Mayo Clin Proc 2007, 82:286-296.

55. Sung JJ, Barkun A, Kuipers EJ, Mossner J, Jensen DM, Stuart R, Lau JY, Ahlbom H, Kilhamn J, Lind T: Intravenous esomeprazole for prevention of recurrent peptic ulcer bleeding: a randomized trial. Ann Intern Med 2009, 150:455-464.

56. Wang $\mathrm{CH}, \mathrm{Ma} \mathrm{MH}$, Chou HC, Yen ZS, Yang CW, Fang CC, Chen SC: High-dose vs non-high-dose proton pump inhibitors after endoscopic treatment in patients with bleeding peptic ulcer: a systematic review and meta-analysis of randomized controlled trials. Arch Intern Med 2010, 170:751-758.

57. Erstad BL: Cost-effectiveness of proton pump inhibitor therapy for acute peptic ulcer-related bleeding. Crit Care Med 2004, 32:1277-1283.

58. Tsoi KK, Chan HC, Chiu PW, Pau CY, Lau JY, Sung JJ: Second-look endoscopy with thermal coagulation or injections for peptic ulcer bleeding: a meta-analysis. J Gastroenterol Hepatol 2010, 25:8-13.

59. Chiu PW, Lam CY, Lee SW, Kwong KH, Lam SH, Lee DT, Kwok SP: Effect of scheduled second therapeutic endoscopy on peptic ulcer rebleeding: a prospective randomised trial. Gut 2003, 52:1403-1407.

60. Saeed ZA, Cole RA, Ramirez FC, Schneider FE, Hepps KS, Graham DY: Endoscopic retreatment after successful initial hemostasis prevents ulcer rebleeding: a prospective randomized trial. Endoscopy 1996 28:288-294.

61. Tsoi K, Chan H, Pao C, Chiu P, Sung J: Is second-look endoscopy with heater probe or injection for peptic ulcer bleeding necessary? Gut 2008, 57:A355.

62. Collins $\mathrm{R}$, Langman M: Treatment with histamine $\mathrm{H} 2$ antagonists in acute upper gastrointestinal hemorrhage. Implications of randomized trials. N Engl J Med 1985, 313:660-666.

63. Levine JE, Leontiadis Gl, Sharma VK, Howden CW: Meta-analysis: the efficacy of intravenous $\mathrm{H} 2$-receptor antagonists in bleeding peptic ulcer. Aliment Pharmacol Ther 2002, 16:1137-1142.

64. Mirsadraee S, Tirukonda P, Nicholson A, Everett SM, McPherson SJ: Embolization for non-variceal upper gastrointestinal tract haemorrhage: a systematic review. Clin Radio/ 2011, 66:500-509.

65. Tang JH, Liu NJ, Cheng HT, Lee CS, Chu YY, Sung KF, Lin CH, Tsou YK, Lien $J M$, Cheng CL: Endoscopic diagnosis of Helicobacter pylori infection by rapid urease test in bleeding peptic ulcers: a prospective case-control study. J Clin Gastroenterol 2009, 43:133-139. 
66. Gisbert JP, Khorrami S, Carballo F, Calvet X, Gene E, Dominguez-Munoz JE: $H$. pylori eradication therapy vs. antisecretory non-eradication therapy (with or without long-term maintenance antisecretory therapy) for the prevention of recurrent bleeding from peptic ulcer. Cochrane Database Syst Rev 2004, 2:CD004062.

67. Biondi-Zoccai GG, Lotrionte M, Agostoni P, Abbate A, Fusaro M, Burzotta F, Testa L, Sheiban I, Sangiorgi G: A systematic review and meta-analysis on the hazards of discontinuing or not adhering to aspirin among 50,279 patients at risk for coronary artery disease. Eur Heart J 2006, 27:2667-2674

68. Aguejouf O, Eizayaga F, Desplat V, Belon P, Doutremepuich C: Prothrombotic and hemorrhagic effects of aspirin. Clin Appl Thromb Hemost 2009, 15:523-528.

69. Ng FH, Wong BC, Wong SY, Chen WH, Chang CM: Clopidogrel plus omeprazole compared with aspirin plus omeprazole for aspirin-induced symptomatic peptic ulcers/erosions with low to moderate bleeding/ re-bleeding risk: a single-blind, randomized controlled study. Aliment Pharmacol Ther 2004, 19:359-365.

70. Sung JJ, Lau JY, Ching JY, Wu JC, Lee YT, Chiu PW, Leung VK, Wong WW, Chan FK: Continuation of low-dose aspirin therapy in peptic ulcer bleeding: a randomized trial. Ann Intern Med 2010, 152:1-9.

71. Gross M, Schiemann U, Muhlhofer A, Zoller WG: Meta-analysis: efficacy of therapeutic regimens in ongoing variceal bleeding. Endoscopy 2001, 33:737-746.

72. Lo GH, Lai KH, Cheng JS, Chen MH, Chiang HT: A prospective, randomized trial of butyl cyanoacrylate injection versus band ligation in the management of bleeding gastric varices. Hepatology 2001, 33:1060-1064.

73. Avgerinos A, Nevens F, Raptis S, Fevery J: Early administration of somatostatin and efficacy of sclerotherapy in acute oesophageal variceal bleeds: the European Acute Bleeding Oesophageal Variceal Episodes (ABOVE) randomised trial. Lancet 1997, 350:1495-1499.

74. Cales P, Masliah C, Bernard B, Garnier PP, Silvain C, Szostak-Talbodec N, Bronowicki JP, Ribard D, Botta-Fridlund D, Hillon P, et al: Early administration of vapreotide for variceal bleeding in patients with cirrhosis. N Engl J Med 2001, 344:23-28.

75. Monescillo A, Martinez-Lagares F, Ruiz-del-Arbol L, Sierra A, Guevara C, Jimenez E, Marrero JM, Buceta E, Sanchez J, Castellot A, et al: Influence of portal hypertension and its early decompression by TIPS placement on the outcome of variceal bleeding. Hepatology 2004, 40:793-801.

76. Garcia-Pagan JC, Caca K, Bureau C, Laleman W, Appenrodt B, Luca A, Abraldes JG, Nevens F, Vinel JP, Mossner J, Bosch J: Early use of TIPS in patients with cirrhosis and variceal bleeding. N Engl J Med 2010, 362:2370-2379.

77. Panes J, Teres J, Bosch J, Rodes J: Efficacy of balloon tamponade in treatment of bleeding gastric and esophageal varices. Results in 151 consecutive episodes. Dig Dis Sci 1988, 33:454-459.

78. Bernard B, Cadranel JF, Valla D, Escolano S, Jarlier V, Opolon P: Prognostic significance of bacterial infection in bleeding cirrhotic patients: a prospective study. Gastroenterology 1995, 108:1828-1834.

79. Goulis J, Armonis A, Patch D, Sabin C, Greenslade L, Burroughs AK: Bacterial infection is independently associated with failure to control bleeding in cirrhotic patients with gastrointestinal hemorrhage. Hepatology 1998, 27:1207-1212

80. Bernard B, Grange JD, Khac EN, Amiot X, Opolon P, Poynard T: Antibiotic prophylaxis for the prevention of bacterial infections in cirrhotic patients with gastrointestinal bleeding: a meta-analysis. Hepatology 1999, 29:1655-1661

81. Lebrec D, Vinel JP, Dupas JL: Complications of portal hypertension in adults: a french consensus. Eur J Gastroenterol Hepatol 2005, 17:403-10.

82. Fernandez J, Ruiz del Arbol L, Gomez C, Durandez R, Serradilla R, Guarner C, Planas R, Arroyo V, Navasa M: Norfloxacin vs ceftriaxone in the prophylaxis of infections in patients with advanced cirrhosis and hemorrhage. Gastroenterology 2006, 131:1049-1056. quiz 1285.

83. Shaheen NJ, Stuart E, Schmitz SM, Mitchell KL, Fried MW, Zacks S, Russo MW, Galanko J, Shrestha R: Pantoprazole reduces the size of postbanding ulcers after variceal band ligation: a randomized, controlled trial. Hepatology 2005, 41:588-594.

84. Trikudanathan G, Israel J, Cappa J, O'Sullivan DM: Association between proton pump inhibitors and spontaneous bacterial peritonitis in cirrhotic patients - a systematic review and meta-analysis. Int J Clin Pract 2011, 65:674-678
85. El-Rifai N, Mention K, Guimber D, Michaud L, Boman F, Turck D, Gottrand F: Gastropathy and gastritis in children with portal hypertension. J Pediatr Gastroenterol Nutr 2007, 45:137-140

86. Castaneda B, Debernardi-Venon W, Bandi JC, Andreu V, Perez-del-Pulgar S, Moitinho E, Pizcueta P, Bosch J: The role of portal pressure in the severity of bleeding in portal hypertensive rats. Hepatology 2000, 31:581-586.

87. Rossaint R, Bouillon B, Cerny V, Coats TJ, Duranteau J, Fernandez-Mondejar E, Hunt BJ, Komadina R, Nardi G, Neugebauer E, et al: Management of bleeding following major trauma: an updated European guideline. Crit Care 2010, 14:R52.

88. Dellinger RP, Levy MM, Carlet JM, Bion J, Parker MM, Jaeschke R, Reinhart K, Angus DC, Brun-Buisson C, Beale R, et al: Surviving Sepsis Campaign: international guidelines for management of severe sepsis and septic shock: 2008. Crit Care Med 2008, 36:296-327.

89. Bosch J, Thabut D, Albillos A, Carbonell N, Spicak J, Massard J, D'Amico G, Lebrec D, de Franchis R, Fabricius $S$, et al: Recombinant factor VIla for variceal bleeding in patients with advanced cirrhosis: A randomized, controlled trial. Hepatology 2008, 47:1604-1614.

90. Souweine B, Van der Linden T, Dupic L, Soufir L, Meyer P, d'experts plg: Prise en charge des thrombopénies en réanimation (pathologies gravidiques exclues). Recommandations formalisées d'experts sous l'égide de la Société de réanimation de langue française (SRLF), avec la participation du Groupe francophone de réanimation et urgences pédiatriques (GFRUP) et du Groupe d'étude hémostase thrombose (GEHT) de la Société française d'hématologie (SFH). Réanimation 2011, 20:264-270

91. Gonzalez R, Zamora J, Gomez-Camarero J, Molinero LM, Banares R, Albillos A: Meta-analysis: combination endoscopic and drug therapy to prevent variceal rebleeding in cirrhosis. Ann Intern Med 2008, 149:109-122.

92. Bandi R, Shetty PC, Sharma RP, Burke TH, Burke MW, Kastan D: Superselective arterial embolization for the treatment of lower gastrointestinal hemorrhage. J Vasc Interv Radiol 2001, 12:1399-1405.

93. Jensen DM, Machicado GA, Jutabha R, Kovacs TO: Urgent colonoscopy for the diagnosis and treatment of severe diverticular hemorrhage. N Engl J Med 2000, 342:78-82.

94. Elta GH: Urgent colonoscopy for acute lower-GI bleeding. Gastrointest Endosc 2004, 59:402-408.

95. Green BT, Rockey DC, Portwood G, Tarnasky PR, Guarisco S, Branch MS, Leung J, Jowell P: Urgent colonoscopy for evaluation and management of acute lower gastrointestinal hemorrhage: a randomized controlled trial. Am J Gastroenterol 2005, 100:2395-2402.

96. Laine L, Shah A: Randomized trial of urgent vs. elective colonoscopy in patients hospitalized with lower GI bleeding. Am J Gastroenterol 2010, 105:2636-2641. quiz 2642.

97. Strate LL, Syngal S: Timing of colonoscopy: impact on length of hospital stay in patients with acute lower intestinal bleeding. Am J Gastroenterol 2003, 98:317-322.

98. Schmulewitz N, Fisher DA, Rockey DC: Early colonoscopy for acute lower Gl bleeding predicts shorter hospital stay: a retrospective study of experience in a single center. Gastrointest Endosc 2003, 58:841-846.

99. Smoot RL, Gostout CJ, Rajan E, Pardi DS, Schleck CD, Harmsen WS, Zinsmeister AR, Nolte T, Melton LJ: Is early colonoscopy after admission for acute diverticular bleeding needed? Am J Gastroenterol 2003 , 98:1996-1999.

100. Wong Kee Song LM, Baron TH: Endoscopic management of acute lower gastrointestinal bleeding. Am J Gastroenterol 2008, 103:1881-1887.

101. Yen EF, Ladabaum U, Muthusamy VR, Cello JP, McQuaid KR, Shah JN: Colonoscopic treatment of acute diverticular hemorrhage using endoclips. Dig Dis Sci 2008, 53:2480-2485.

102. Bloomfeld RS, Rockey DC, Shetzline MA: Endoscopic therapy of acute diverticular hemorrhage. Am J Gastroenterol 2001, 96:2367-2372.

103. Lin CC, Lee YC, Lee H, Lin JT, Ho WC, Chen TH, Wang HP: Bedside colonoscopy for critically ill patients with acute lower gastrointestinal bleeding. Intensive Care Med 2005, 31:743-746.

104. Misra SP, Dwivedi M, Misra V: lleoscopy in 39 hematochezia patients with normal colonoscopy. World J Gastroenterol 2006, 12:3101-3104.

105. Prakash C, Zuckerman GR: Acute small bowel bleeding: a distinct entity with significantly different economic implications compared with Gl bleeding from other locations. Gastrointest Endosc 2003, 58:330-335. 
106. Tryba M, Huchzermeyer H, Torok M, Zenz M, Pahlow J: Single-drug and combined medication with cimetidine, antacids and pirenzepine in the prophylaxis of acute upper gastrointestinal bleeding. Hepatogastroenterology 1983, 30:154-157.

107. Lewis JD, Shin EJ, Metz DC: Characterization of gastrointestinal bleeding in severely ill hospitalized patients. Crit Care Med 2000, 28:46-50.

108. Ben-Menachem T, Fogel R, Patel RV, Touchette M, Zarowitz BJ, Hadzijahic N, Divine G, Verter J, Bresalier RS: Prophylaxis for stress-related gastric hemorrhage in the medical intensive care unit. A randomized, controlled, single-blind study. Ann Intern Med 1994, 121:568-575.

109. Cook DJ, Fuller HD, Guyatt GH, Marshall JC, Leasa D, Hall R, Winton TL, Rutledge F, Todd TJ, Roy P, et al: Risk factors for gastrointestinal bleeding in critically ill patients. Canadian critical care trials group. N Engl J Med 1994, 330:377-381.

110. Schuster DP, Rowley H, Feinstein S, McGue MK, Zuckerman GR: Prospective evaluation of the risk of upper gastrointestinal bleeding after admission to a medical intensive care unit. Am J Med 1984, 76:623-630.

111. Cook D, Heyland D, Griffith L, Cook R, Marshall J, Pagliarello J: Risk factors for clinically important upper gastrointestinal bleeding in patients requiring mechanical ventilation. Canadian critical care trials group. Crit Care Med 1999, 27:2812-2817.

112. Reveiz L, Guerrero-Lozano R, Camacho A, Yara L, Mosquera PA: Stress ulcer, gastritis, and gastrointestinal bleeding prophylaxis in critically ill pediatric patients: a systematic review. Pediatr Crit Care Med 2010, 11:124-132

113. Chaibou M, Tucci M, Dugas MA, Farrell CA, Proulx F, Lacroix J: Clinically significant upper gastrointestinal bleeding acquired in a pediatric intensive care unit: a prospective study. Pediatrics 1998, 102:933-938.

114. Deerojanawong J, Peongsujarit D, Vivatvakin B, Prapphal N: Incidence and risk factors of upper gastrointestinal bleeding in mechanically ventilated children. Pediatr Crit Care Med 2009, 10:91-95.

115. Kuusela AL, Maki M, Ruuska T, Laippala P: Stress-induced gastric findings in critically ill newborn infants: frequency and risk factors. Intensive Care Med 2000, 26:1501-1506.

116. Nithiwathanapong C, Reungrongrat S, Ukarapol N: Prevalence and risk factors of stress-induced gastrointestinal bleeding in critically ill children. World J Gastroenterol 2005, 11:6839-6842.

117. Robertson MS, Cade JF, Clancy RL: Helicobacter pylori infection in intensive care: increased prevalence and a new nosocomial infection. Crit Care Med 1999, 27:1276-1280.

118. Ellison RT, Perez-Perez G, Welsh CH, Blaser MJ, Riester KA, Cross AS, Donta ST, Peduzzi P: Risk factors for upper gastrointestinal bleeding in intensive care unit patients: role of helicobacter pylori. Federal Hyperimmune Immunoglobulin Therapy Study Group. Crit Care Med 1996, 24:1974-1981.

119. van der Voort PH, van der Hulst RW, Zandstra DF, Geraedts AA, van der Ende A, Tytgat GN: Prevalence of Helicobacter pylori infection in stress-induced gastric mucosal injury. Intensive Care Med 2001, 27:68-73.

120. Maury E, Tankovic J, Ebel A, Offenstadt G: An observational study of upper gastrointestinal bleeding in intensive care units: is Helicobacter pylori the culprit? Crit Care Med 2005, 33:1513-1518.

121. Schilling D, Haisch G, Sloot N, Jakobs R, Saggau W, Riemann JF: Low seroprevalence of Helicobacter pylori infection in patients with stress ulcer bleeding-a prospective evaluation of patients on a cardiosurgical intensive care unit. Intensive Care Med 2000, 26:1832-1836.

122. Robert R, Gissot V, Pierrot M, Laksiri L, Mercier E, Prat G, Villers D, Vincent JF, Hira $M$, Vignon $P$, et al: Helicobacter pylori infection is not associated with an increased hemorrhagic risk in patients in the intensive care unit. Crit Care 2006, 10:R77.

123. Cook DJ, Witt LG, Cook RJ, Guyatt GH: Stress ulcer prophylaxis in the critically ill: a meta-analysis. Am J Med 1991, 91:519-527.

124. Cook D, Guyatt G, Marshall J, Leasa D, Fuller H, Hall R, Peters S, Rutledge F, Griffith L, McLellan A, et al: A comparison of sucralfate and ranitidine for the prevention of upper gastrointestinal bleeding in patients requiring mechanical ventilation. Canadian critical care trials group. $N$ Engl J Med 1998, 338:791-797.
125. Conrad SA, Gabrielli A, Margolis B, Quartin A, Hata JS, Frank WO, Bagin RG, Rock JA, Hepburn B, Laine L: Randomized, double-blind comparison of immediate-release omeprazole oral suspension versus intravenous cimetidine for the prevention of upper gastrointestinal bleeding in critically ill patients. Crit Care Med 2005, 33:760-765.

126. Lin PC, Chang $\mathrm{CH}$, Hsu PI, Tseng PL, Huang YB: The efficacy and safety of proton pump inhibitors vs histamine-2 receptor antagonists for stress ulcer bleeding prophylaxis among critical care patients: a meta-analysis. Crit Care Med 2010, 38:1197-1205

doi:10.1186/2110-5820-2-46

Cite this article as: Osman et al:: Management by the intensivist of gastrointestinal bleeding in adults and children. Annals of Intensive Care 2012 2:46.

\section{Submit your manuscript to a SpringerOpen ${ }^{\odot}$ journal and benefit from:}

- Convenient online submission

- Rigorous peer review

- Immediate publication on acceptance

- Open access: articles freely available online

- High visibility within the field

- Retaining the copyright to your article

Submit your next manuscript at $>$ springeropen.com 